\title{
Dental calculus is not equivalent to bone collagen for isotope analysis: a comparison between carbon and nitrogen stable isotope analysis of bulk dental calculus, bone and dentine collagen from same individuals from the Medieval site of El Raval (Alicante, Spain)
}

\author{
D.C. Salazar-García a,b,c, d, ${ }^{\text {, M.P. Richards }}{ }^{\text {b,e,f }}$, O. Nehlich ${ }^{\text {b,e }}$, A.G. Henry ${ }^{\text {a }}$ \\ ${ }^{a}$ Research Group on Plant Foods in Hominin Dietary Ecology, Max Planck Institute for Evolutionary Anthropology, Leipzig, Germany \\ ${ }^{\mathrm{b}}$ Department of Human Evolution, Max Planck Institute for Evolutionary Anthropology, Leipzig, Germany \\ ${ }^{\mathrm{c}}$ Department of Archaeology, University of Cape Town, Cape Town, South Africa \\ ${ }^{\mathrm{d}}$ Departament de Prehistòria i Arqueologia, Universitat de València, Valencia, Spain \\ e Department of Anthropology, University of British Columbia, Vancouver, Canada \\ ${ }^{\mathrm{f}}$ Department of Archaeology, University of Durham, Durham, UK
}

\section{A R T I C L E I N F O}

\section{Article history:}

Received 7 December 2013

Received in revised form

22 March 2014

Accepted 24 March 2014

Available online $\mathrm{xxx}$

\section{Keywords:}

Stable isotopes

Collagen

Dental calculus

Diet

Medieval period

\begin{abstract}
A B S T R A C T
Palaeodietary reconstruction using the carbon and nitrogen isotope values of bone and dentine collagen is a well-established method and the biochemical processes involved are well known. Researchers have recently explored using bulk samples of dental calculus as a substitute for bone and dentine collagen in dietary analyses, because calculus can be sampled without causing damage to the teeth, and may be useful in situations where more destructive analyses are not possible, or where collagen is poorly preserved. Several questions remain about the use of bulk calculus as a source of carbon and nitrogen isotope data, however. It is not yet clear how much of an individual's life span dental calculus represents, what portions of the diet it records, and how diagenesis effects the carbon and nitrogen isotope values of this material. Most importantly, there have been no comparative studies of collagen and calculus isotope values, which are necessary to establish the value of bulk calculus as a source of accurate isotope values. Here we report the comparison of carbon and nitrogen stable isotope analyses of bulk calculus to those from bone and dentine collagen. These analyses have been performed on individuals from the El Raval Mudéjar Medieval Cemetery (Eastern Iberia, 15th century A.D.). Although calculus isotope values may be broadly similar to expected values at the population level, we report here no correlation between collagen and bulk dental calculus values at the individual level. As a result, we recommend that carbon and nitrogen analysis on bulk dental calculus should only be used as a last resource archaeological dietary marker, if at all.
\end{abstract}

(c) 2014 Elsevier Ltd. All rights reserved.

\section{Introduction}

Over the last several decades, carbon $\left(\delta^{13} \mathrm{C}\right)$ and nitrogen $\left(\delta^{15} \mathrm{~N}\right)$ isotope analysis of dentine and bone collagen has been established as a reliable tool to recover information on past human diets (e.g. Katzenberg, 2000; Lee-Thorp, 2008; Sealy, 2001). There are a few known limitations to using these sources for isotopic analysis. The

\footnotetext{
* Corresponding author. Research Group on Plant Foods in Hominin Dietary Ecology, Max Planck Institute for Evolutionary Anthropology, Leipzig, Germany. Tel.: +493413550364.

E-mail addresses: domingo_carlos@eva.mpg.de, domingocarlos.salazar@uv.es (D.C. Salazar-García).
}

collagen must be well preserved, and it represents only a broadly averaged, long-term, multi-year dietary protein intake (e.g. SalazarGarcía et al., 2014). Therefore, recent research has investigated whether there are other biological materials that can be used for isotope analysis, such as coprolites (Ghosh et al., 2003), carbonized sherd residues (Hart et al., 2009) and animals with human-like diets (Guiry and Grimes, 2013).

Dental calculus (mineralized plaque) has recently been identified as a substrate for multiple kinds of dietary analysis. Plant microremains (e.g. starch grains and phytoliths) recovered from calculus have provided information about plant consumption (e.g. Henry et al., 2011, 2012; Lalueza-Fox et al., 1996; Power et al., 2014; Salazar-García et al., 2013; Scott Cummings and Magennis, 1997). 
A) EDX spectrum of enamel

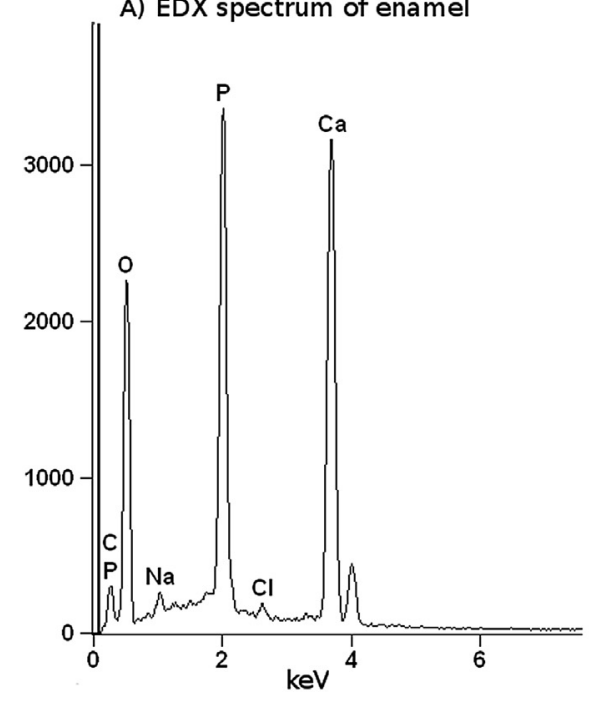

B) EDX spectrum of calculus

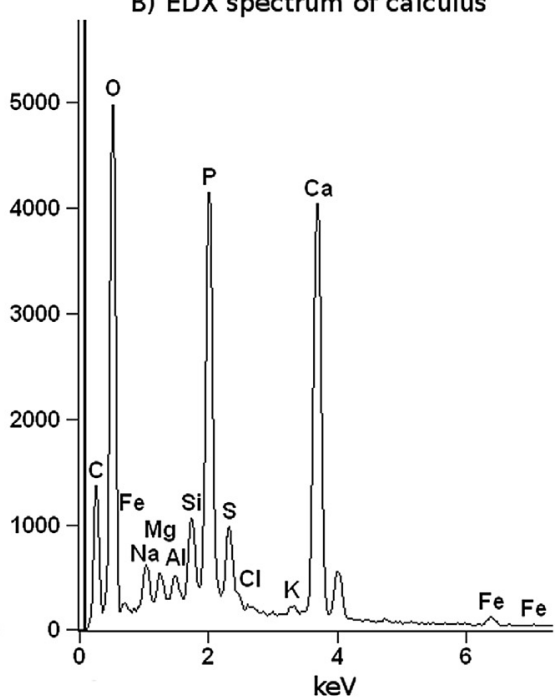

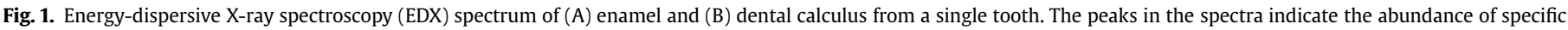

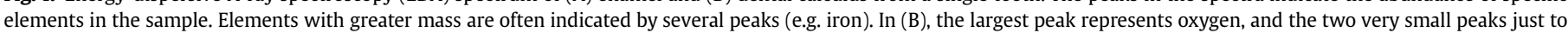
the right of the oxygen peak are iron and sodium respectively.

Food and bacteria proteins and DNA are also preserved in calculus, which can give information about diet and health (Adler et al., 2013; Warinner et al., 2014). Some researchers have attempted to use dental calculus as a source for carbon and nitrogen isotopes (Poulson et al., 2013; Scott and Poulson, 2012). These studies assume that carbon and nitrogen isotope values from bulk dental calculus can be interpreted in the same way as those from bone or dentine collagen. Here we report on the results of tests that explore the relationship between collagen and bulk calculus carbon and nitrogen isotope values.

\section{1. $C$ and $N$ isotope analysis and dietary reconstruction}

Carbon and nitrogen stable isotope analysis relies on the principle that the isotopic composition of food eaten by both animals and humans is recorded in their body tissues after a predictable isotope fractionation (Schoeller, 1999). Collagen is usually the preferred substrate for these analyses, because it is the only considerable nitrogen source from skeletal remains, its biochemistry is well known, and it has accepted quality indicators (De Niro, 1985; Van Klinken, 1999). Stable isotope ratios of collagen reflect the isotopic signals of the main dietary protein sources, rather than that of a diet as a whole (Ambrose and Norr, 1993). Results obtained on bone collagen average the dietary protein consumed during several years prior to death, depending on the collagen turnover rate of the bone sampled (Hedges et al., 2007). In contrast, dentine collagen has almost no turnover, so the isotope values reflect protein diet consumed during the short interval in which the dentine of each tooth was formed (Beaumont et al., 2012).

The stable carbon isotope values can either distinguish between the consumption of $\mathrm{C}_{4}\left({ }^{13} \mathrm{C}\right.$ enriched) and $\mathrm{C}_{3}\left({ }^{13} \mathrm{C}\right.$ depleted $)$ terrestrial resources (Van der Merwe and Vogel, 1978), or it can define the input of marine $\left({ }^{13} \mathrm{C}\right.$ enriched) or terrestrial $\left({ }^{13} \mathrm{C}\right.$ depleted) foods in the diet (Chisholm et al., 1982). The nitrogen stable isotope ratio is usually an indication of trophic level, since it increases by $3-5 \%$ each step up the food-chain (De Niro and Epstein, 1981; Schoeninger and De Niro, 1984). This allows us to generally distinguish diets rich in plant proteins from those rich in animal proteins (Minagawa and Wada, 1984), with some acknowledgement of inherent variation among these values
(Hedges and Reynard, 2007). Nitrogen stable isotope ratios may also be useful to detect the consumption of ${ }^{15} \mathrm{~N}$ enriched aquatic foods versus relatively ${ }^{15} \mathrm{~N}$ depleted terrestrial food sources such as domestic animals (Schoeninger et al., 1983). When combined, nitrogen and carbon values can discriminate between the consumption of aquatic foods and $\mathrm{C}_{4}$ terrestrial foods.

\subsection{Composition and formation of dental calculus}

Dental calculus is the mineralized plaque that forms on the surface of teeth (Jin and Yip, 2002; Lieverse, 1999). Saliva is saturated in calcium phosphate in order to prevent the dissolution of the teeth during consumption of acidic foods. Oral bacteria form a pellicle on the surface of the teeth and this roughened surface is a site for precipitation of calcium phosphate. Bacteria then grow through and on top of the calcium phosphate, causing the calculus to accumulate. During this process, food particles, bacteria, human proteins and enzymes, and other constituents become trapped in the mineral context. Environmental scanning electron microscopy analysis coupled with energy-dispersive X-ray spectroscopy (ESEM-EDX) of calculus indicates that its elemental constituents are very similar to enamel, containing a high percentage of calcium and phosphate, but also several other elements including carbon (Fig. 1). The enamel is almost exclusively calcium, phosphate and oxygen, indicating hydroxyapatite. The major components of the calculus are calcium, phosphate and oxygen, consistent with hydroxyapatite. Minor components include carbon, sulphur, iron, silicon, sodium, aluminium, magnesium and chlorine indicating the presence of organics, salts and other minerals. The strongly mineralized nature of calculus may provide a protected context for archaeologically relevant residues.

Research on modern calculi has demonstrated that traces of food and other remains can be found within the mineral phase. Therefore, dental calculus might be a useful source of information for dietary reconstruction. However, the nature of the formation of dental calculus seems to be highly individualistic and uncertain. The rate and amount of calculus formation depends on the specific diet, particularly on the relative proportion of meat and other ureainducing and high-pH foods (Jin and Yip, 2002; Lieverse, 1999) as well as sugars (Scheie, 1994), on genetic variations in salivary 
content (Nancollas and Johnsson, 1994), and many other factors, including age, race, sex, disease, and bacterial load (Nancollas and Johnsson, 1994; White, 1997). Furthermore, relatively little is known about the rate of calculus formation and possibly dissolution throughout an individual's life, and how this might vary from individual to individual. Finally, bulk calculus is a mix of particles derived from the host, from the food the host has consumed, from other items that were placed in the mouth or smoked, and from the bacteria living in the oral cavity. Therefore it is unclear and highly variable if and how the diet is recorded in the calculus.

Though calculus has been successfully used in dietary studies using other methods, and though several studies have examined the isotope values of bulk calculus, no work has been done to test whether it is a reliable source for isotope values. Here we present the first comparison of the isotope values from bulk calculus, bone collagen and dentine collagen, with the goal of testing whether calculus isotope values can be used in place of the values from collagen.

\section{Material and methods}

We have sampled and analysed bulk dental calculus, bone collagen and dentine collagen of 35 adult individuals from a population of the medieval cemetery of El Raval (Alicante, Spain). Details for all of the individual samples are presented in Tables S1-S5 of the Supplementary information. There were no animal remains at the site, so we were unable to compare the human and faunal values.

\subsection{The site of El Raval}

El Raval is a medieval necropolis in the city of Crevillent (Alicante, Spain), from the Kingdom of València, Crown of Aragón (Fig. 2). The cemetery was originally situated outside the city wall, beside one of the main roads into the city. The whole necropolis has been radiocarbon dated to between the end of the 14th century A.D. and the beginning of the 16th century A.D. (Trelis Martí et al., 2009). The study of the burial customs used in the cemetery revealed that most of the interred individuals were Mudéjar, Muslims of AlAndalus that remained in Iberia after the Christian Conquest (Trelis Marti et al., 2007, 2010). A minority were Islamic people who had converted to Christianity (Trelis Marti et al., 2007, 2010). Most of the individuals were buried in single graves, which were only occasionally covered by rocks or wood. A total of 81 burials have been recovered from both sectors of the necropolis. Individuals of all ages, except for those $>60$ years, were buried in the cemetery. Infants ( $0-4$ years) and full adults were the most frequent burials. Oral pathologies are frequent among the adults, with many individuals having dental calculus, caries, periodontal disease and antemortem tooth loss (De Miguel Ibáñez, 2007).

We selected 35 individuals, including 16 males ( 3 young adults, 10 adults, 3 mature adults), 13 females ( 1 young adult, 7 adults, 5 mature adults), and 6 of indeterminate sex ( 5 young adults, 1 mature adult). We collected bone collagen samples from ribs. The dentine collagen samples came mostly from molars, though we chose other teeth when molars were unavailable. For each individual, we collected much of the visible calculus and combined the calculi from all teeth to ensure an adequate sample size and to average inter-tooth variation.

\subsection{Collagen extraction}

Prior to the extraction itself, visible contaminants were removed with aluminium oxide powder abrasion from both the bone and dentine samples. Collagen extraction then proceeded following

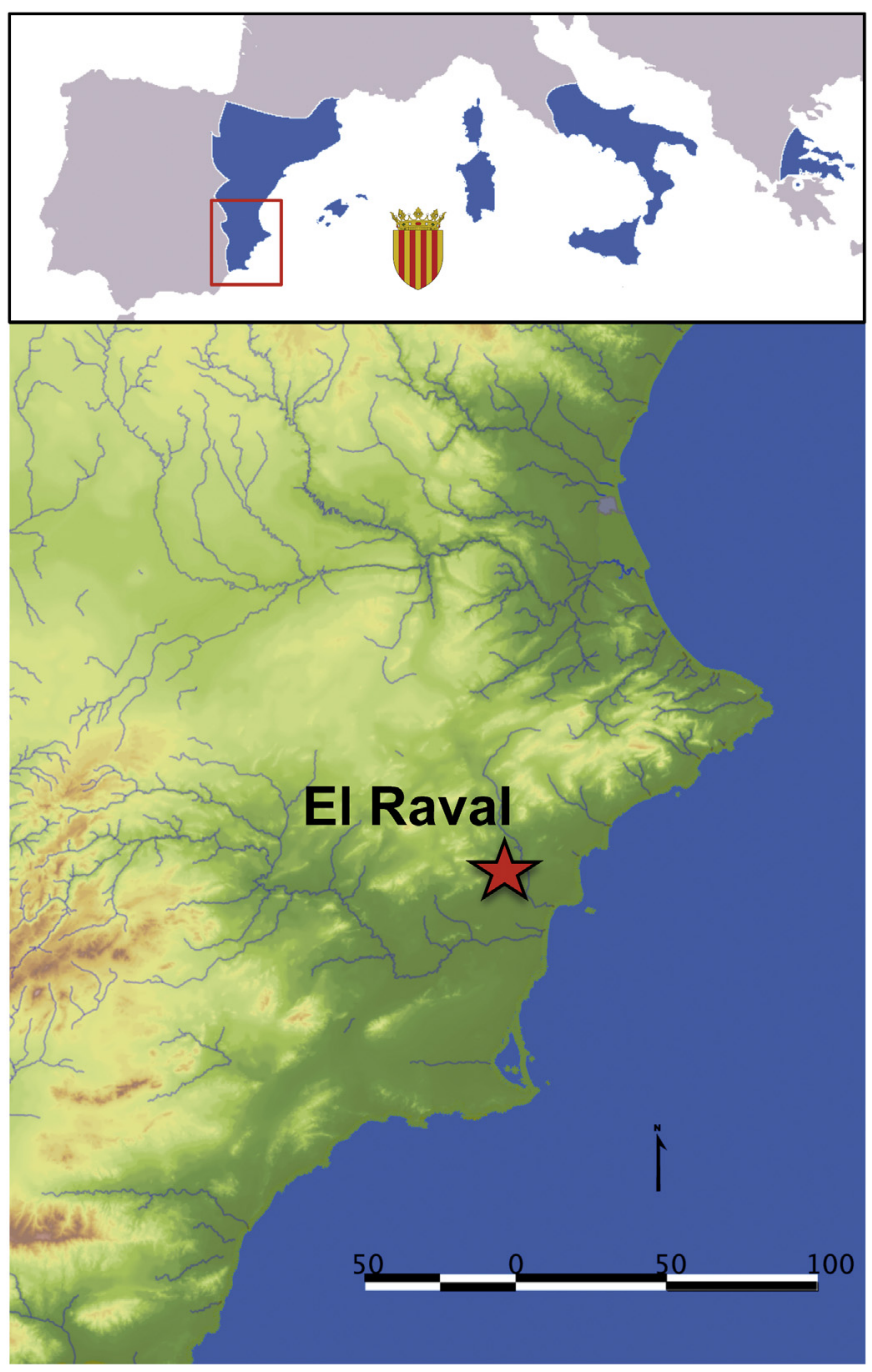

Fig. 2. Map with the location of the medieval site of El Raval (red star) in the Crown of Aragón (shaded in blue). (For interpretation of the references to colour in this figure legend, the reader is referred to the web version of this article.).

Richards and Hedges (1999), with the addition of an ultrafiltration step (Brown et al., 1988). In summary, whole bone pieces between 300 and $500 \mathrm{mg}$ and whole dentine chunks between 100 and $200 \mathrm{mg}$ from each individual were placed in $0.5 \mathrm{M} \mathrm{HCl}$ solution at $5{ }^{\circ} \mathrm{C}$ over the course of $1-3$ weeks until demineralized, and were then rinsed three times with deionized water until reaching neutral $\mathrm{pH}$. This was followed by gelatinization over $48 \mathrm{~h}$ at $70^{\circ} \mathrm{C}$, and then by filtering with a $5 \mu \mathrm{m}$ EZEE $^{\odot}$ filter and ultrafiltering with $>30 \mathrm{kDa}$ Amicon $^{\odot}$ ultrafilters. The purified solution was finally frozen and lyophilized before being weighed into tin capsules and loaded into the mass spectrometers.

\subsection{Dental calculus sampling and preparation}

All of the individuals had ample dental calculus, distributed on the surfaces of the enamel and enamel-dentine junction of most teeth, with the greatest accumulations on the incisors and molars (Fig. 3). The surfaces of the dental calculus were gently brushed with a sterilized disposable toothbrush in order to remove any surface contamination before sampling. The calculus was removed by careful scraping with the edge of a dental scaler, so that the calculus fell onto weighing paper, from which it was then 

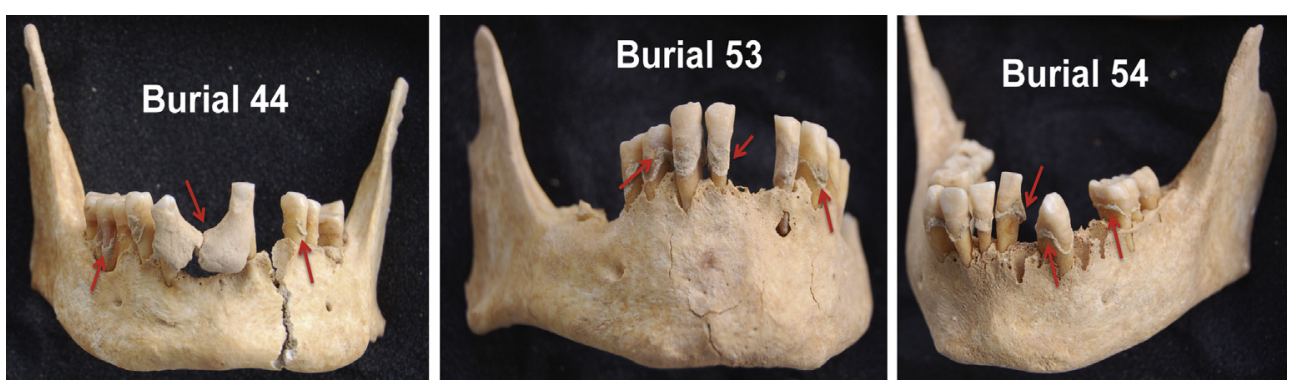

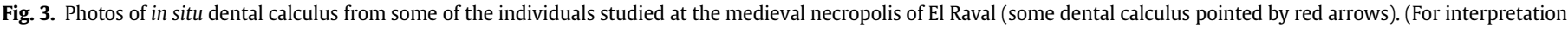
of the references to colour in this figure legend, the reader is referred to the web version of this article.).

transferred into a microcentrifuge tube. We sampled several teeth from each individual, removing the entire calculus deposit from each tooth, and combining the calculus samples into one tube. However, we did not sample all teeth, in order to ensure that some calculus remained in situ for potential future studies.

Samples were then transferred to the laboratory of the Plant Foods in Hominin Dietary Ecology research group at the MaxPlanck Institute for Evolutionary Anthropology (Leipzig, Germany), where they were further processed prior to analysis. All calculi sampled from each individual were manually homogenized with cleaned marble mortar and pestle, until the resulting sample was a fine powder. We then took multiple subsamples of the homogenized mass: $0.5 \mathrm{mg}$ for each of the 35 individuals. Our previous work with faunal dental calculus indicated that samples as small as $0.5 \mathrm{mg}$ yielded measurable nitrogen peaks, and that the results from this small quantity were consistent with those from larger quantities of the same calculus sample, up to at least $10 \mathrm{mg}$ (Salazar-García et al., 2012).

\subsection{Carbon and nitrogen isotope analysis}

The carbon and nitrogen isotope ratios of collagen and homogenised bulk dental calculus were measured at the Department of Human Evolution, Max-Planck Institute for Evolutionary Anthropology (Leipzig, Germany) in duplicate. The samples were combusted in an elemental analyzer Flash EA 2112 coupled to a Delta XP continuous-flow isotope ratio mass spectrometer (Thermo-Finnigan $^{\odot}$, Bremen, Germany). Stable carbon isotope ratios were measured relative to the VPDB scale (Vienna PeeDee Belemnite) and stable nitrogen isotope ratios were analysed relative to the AIR scale (atmospheric $\mathrm{N}_{2}$ ), the results being expressed with delta notation $(\delta)$ in parts per mil $(\%)$. Repeated analysis of internal and international standards determined an analytical error better than $\pm 0.2 \%$ o $(1 \sigma)$ for both $\delta^{13} \mathrm{C}$ and $\delta^{15} \mathrm{~N}$ values.

\section{Results}

\subsection{Carbon and nitrogen quality indicators on collagen and dental} calculus

Human bone and dentine collagen samples yielded enough collagen in the $>30 \mathrm{kDa}$ fraction for analysis in duplicate, and met published collagen quality criteria (Ambrose, 1993; Van Klinken, 1999).

However, analysis and interpretation of carbon and nitrogen stable isotopes on bulk dental calculus is still in the exploratory stage, and one of the main concerns of this technique is that bulk calculus is not, and should not behave like, collagen. Therefore, we expect that the values for $\% \mathrm{C}, \% \mathrm{~N}$ and $\mathrm{C}: \mathrm{N}$ ratio that indicate well preserved archaeological collagen $(\% \mathrm{C}[>35 \%], \% \mathrm{~N}[>10 \%], \mathrm{C}: \mathrm{N}$ ratio
[2.9-3.6]) (De Niro, 1985) are not relevant to understanding the preservation quality of calculus. We therefore provide these parameters only for comparison (Table $1 \mathrm{a}$ ), since there are no quality markers for dental calculus yet published. The \%C, \%N and C: $\mathrm{N}$ ratios of the dental calculus are quite different to what is expected for bone/dentine collagen, and highly variable (Table $1 \mathrm{a}$ ). In particular, the C:N ratio value is extremely variable between samples (ranging from 3.2 to 44.5). However, there is no correlation between the $\delta^{13} \mathrm{C}$ and $\delta^{15} \mathrm{~N}$ values with the amount of carbon and nitrogen. When such a correlation is present, it indicates a chemical intrusion of environmental contaminants into the analysed material and most likely a change of the isotopic value towards the environmental composition. We find no evidence for this environmental contamination in our data.

\subsection{Carbon and nitrogen isotope results on bone and dentine collagen}

The mean bone collagen $\delta^{13} \mathrm{C}$ value is $-16.4 \pm 0.6(1 \sigma) \%$ (min: $-17.5 \%$, max: $-15.0 \%$ ) (Table $1 \mathrm{~b}$ ), which is consistent with a diet based on a mix of $C_{3}$ and $C_{4}$ resources, or on marine and terrestrial protein. Their mean $\delta^{15} \mathrm{~N}$ value is $12.1 \pm 0.3(1 \sigma) \%$ (min: $11.4 \%$, max: $13.0 \%$ ). While we are unable to assess the amount of animal and plant protein in their diet because we lack a comparative faunal data set, the narrow range of nitrogen values suggest that all the individuals shared a similar diet at the same trophic level. The combination of relatively low $\delta^{15} \mathrm{~N}$ values with enriched $\delta^{13} \mathrm{C}$ values suggest that the dominant diet most likely included terrestrial rather than marine foods (De Niro and Epstein, 1978; Schwarcz and Schoeninger, 1991). In summary, the diet of this population was quite homogeneous, and consisted of both $\mathrm{C}_{4}$ and $\mathrm{C}_{3}$ terrestrial resources.

A similar pattern appears in the carbon and nitrogen stable isotope ratios from dentine collagen (Table 1b). Their mean $\delta^{13} \mathrm{C}$ value is $-16.2 \pm 0.8(1 \sigma) \%$ (min: $-17.5 \%$, max: $-14.0 \%$ ), and the mean $\delta^{15} \mathrm{~N}$ value is $12.3 \pm 0.7(1 \sigma) \%$ ( $\min : 10.9 \%$, max: $14.0 \%$ ). Since dentine collagen reflects a shorter time period than bone collagen, and from childhood instead of a few years prior to death, the similarity in values between bone and dentine collagen suggests that the diet of this population was not only homogeneous but also quite stable during the lifetime of the individuals studied. The slightly higher variation in nitrogen values in the dentine may be a reflection of breastfeeding and subsequent weaning captured in the nitrogen isotopes values of the teeth of some individuals and not others (Eerkens et al., 2011).

\subsection{Carbon and nitrogen isotope values on dental calculus}

The $\delta^{13} \mathrm{C}$ mean value on human bulk dental calculus is $-15.5 \pm 2.8(1 \sigma) \%$ ( $\min :-19.7 \%$ o $\max :-5.8 \%$ o , and their $\delta^{15} \mathrm{~N}$ 
Table 1

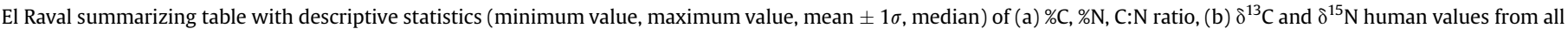
three substrates (bone collagen, dentine collagen, bulk calculus).

\begin{tabular}{|c|c|c|c|c|c|c|c|c|c|}
\hline (a) & \%C Bone coll. & \%C Dent. coll. & \%C Bulk calc. & \%N Bone coll. & \%N Dent. coll. & \%N Bulk calc. & C:N Bone coll. & C:N Dent. coll. & C:N Bulk calc. \\
\hline Mean $\pm 1 \sigma$ & $40.8 \pm 3.5$ & $43.4 \pm 1.4$ & $4.7 \pm 1.9$ & $14.9 \pm 1.1$ & $15.8 \pm 0.6$ & $0.6 \pm 0.3$ & $3.2 \pm 0.1$ & $3.2 \pm 0.1$ & $11.2 \pm 8.7$ \\
\hline Median & 41.7 & 42.7 & 4.2 & 15.3 & 15.6 & 0.5 & 3.2 & 3.2 & 8.0 \\
\hline Minimum value & 33.0 & 40.9 & 2.3 & 12.2 & 14.6 & 0.3 & 3.1 & 3.0 & 4.2 \\
\hline Maximum value & 45.5 & 45.8 & 12.4 & 16.5 & 17.3 & 2.2 & 3.3 & 3.3 & 44.5 \\
\hline (b) & \multicolumn{2}{|c|}{$\delta^{13} \mathrm{C}$ Bone coll. } & $\delta^{13} \mathrm{C}$ Dent. coll. & \multicolumn{2}{|c|}{$\delta^{13} \mathrm{C}$ Bulk calc. } & $\delta^{15} \mathrm{~N}$ Bone coll. & \multicolumn{2}{|c|}{$\delta^{15} \mathrm{~N}$ Dent. coll. } & $\delta^{15} \mathrm{~N}$ Bulk calc. \\
\hline Mean $\pm 1 \sigma$ & \multicolumn{2}{|c|}{$-16.4 \pm 0.6$} & $-16.2 \pm 0.8$ & \multicolumn{2}{|c|}{$-15.5 \pm 2.8$} & $12.1 \pm 0.3$ & \multicolumn{2}{|c|}{$12.3 \pm 0.7$} & $12.2 \pm 1.4$ \\
\hline Median & \multirow{2}{*}{\multicolumn{2}{|c|}{$\begin{array}{l}-16.4 \\
-17.5\end{array}$}} & -16.4 & \multicolumn{2}{|c|}{-16.1} & 12.1 & \multicolumn{2}{|c|}{12.3} & 12.2 \\
\hline Minimum value & & & -17.5 & \multirow{2}{*}{\multicolumn{2}{|c|}{$\begin{array}{l}-19.7 \\
-5.8\end{array}$}} & 11.4 & \multicolumn{2}{|l|}{10.9} & 8.9 \\
\hline Maximum value & \multicolumn{2}{|l|}{-15.0} & -14.0 & & & 13.0 & 14.0 & & 15.1 \\
\hline
\end{tabular}

mean value is $12.2 \pm 1.4(1 \sigma) \%$ ( $\min : 8.9 \%$, $\max : 15.1 \%$ ). If interpreted as collagen values, the calculus $\mathrm{C}$ and $\mathrm{N}$ values suggest that some individuals in this population consumed mainly $\mathrm{C}_{3}$ terrestrial resources, some mainly $\mathrm{C}_{4}$ resources, and others a mixed diet of $C_{3} / C_{4}$ terrestrial resources, with no isotopic evidence for any marine or freshwater protein consumption. By using carbon and nitrogen stable isotope ratios on bulk dental calculus, we would determine than the diet of this population was very heterogeneous, which is a completely different conclusion than that indicated by bone and dentine collagen.

\subsection{Dental calculus vs. collagen isotopic values from same individuals}

The population average $\delta^{13} \mathrm{C}$ and $\delta^{15} \mathrm{~N}$ values of the three substrates are similar (Table $1 \mathrm{~b}$ ), which might lead to the interpretation that bulk calculus can be a reliable source for palaeodietary reconstructions. However, there is a high individual variability in both carbon and nitrogen isotope values for dental calculus compared to bone and dentine collagen isotope results (Fig. 4), leading to different interpretations if studied alone. The ranges of carbon and nitrogen isotope values for calculus are much wider than those observed on bone and dental collagen.

Furthermore, there is no clear correlation between the carbon and nitrogen isotopic values from bulk dental calculus and those from bone and dentine collagen within individuals. In some individuals, the $\delta^{13} \mathrm{C}$ values of the different tissues are similar; in others they are quite different (Fig. 5a). In all cases, bone and dentine collagen values group closely together, but bulk calculus values can be up to $10 \%$ different, which in an extreme example could mean the difference between a mostly $C_{3}$ and a mostly $C_{4}$ terrestrial diet. Nitrogen values show a similar pattern, with some

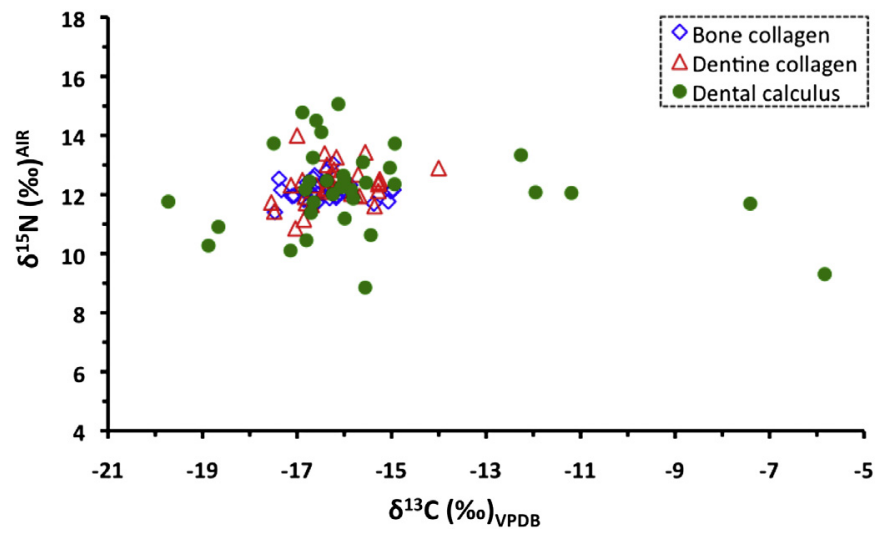

Fig. 4. El Raval human $\delta^{13} \mathrm{C}$ and $\delta^{15} \mathrm{~N}$ values from bone collagen, dentine collagen, and bulk dental calculus. individuals having similar ratios, and others up to $5 \%$ different (Fig. 5b), which is usually associated with an entire trophic level difference.

Tests for correlation between bone collagen and bulk calculus $\delta^{13} \mathrm{C}$ and $\delta^{15} \mathrm{~N}$ values show no relationship between these tissues (carbon $R^{2}=0.23$, nitrogen $R^{2}=0.17$, Fig. 6 a and b), which means both isotopic proxies are independent from each other and must be evaluated separately. The same is true for dentine collagen and bulk calculus (carbon $R^{2}=0.03$, nitrogen $R^{2}=0.19$, Fig. $6 \mathrm{c}$ and d).

Because the isotope values are much more variable in the dental calculus samples, we could not use paired $T$-tests to compare these populations (i.e., they violate the assumption of normalcy). In fact, the calculus $\delta^{13} \mathrm{C}$ values and $\delta^{15} \mathrm{~N}$ values have variances that are an order of magnitude higher than those of bone and dentine collagen (Table 2). F-tests for differences in the variance confirm that these differences in the variances are significant and show that calculus $\delta^{13} \mathrm{C}$ values and $\delta^{15} \mathrm{~N}$ values are highly significantly more variable than those from bone and dentine collagen (Table 2). As mentioned previously, dentine collagen $\delta^{15} \mathrm{~N}$ values are also significantly greater than bone collagen values, though within the same order of
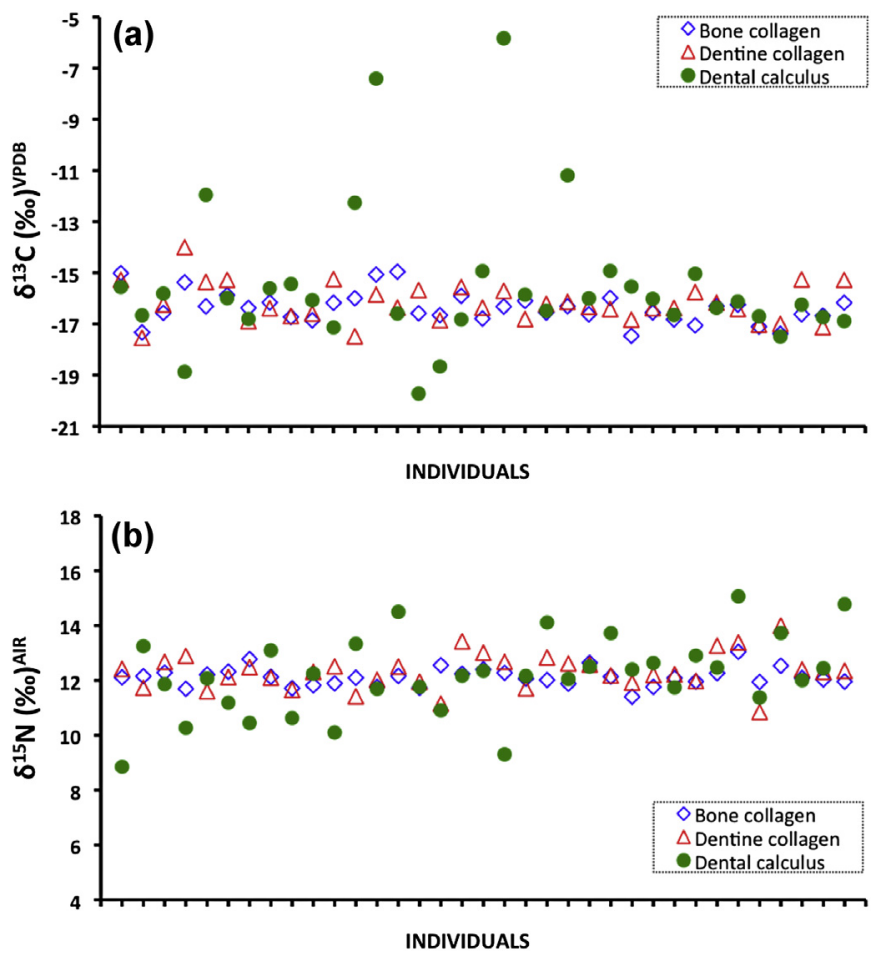

Fig. 5. Graphs showing (a) $\delta^{13} \mathrm{C}$ and (b) $\delta^{15} \mathrm{~N}$ values individually for bone collagen, dentine collagen, and bulk dental calculus from the individuals of El Raval. 

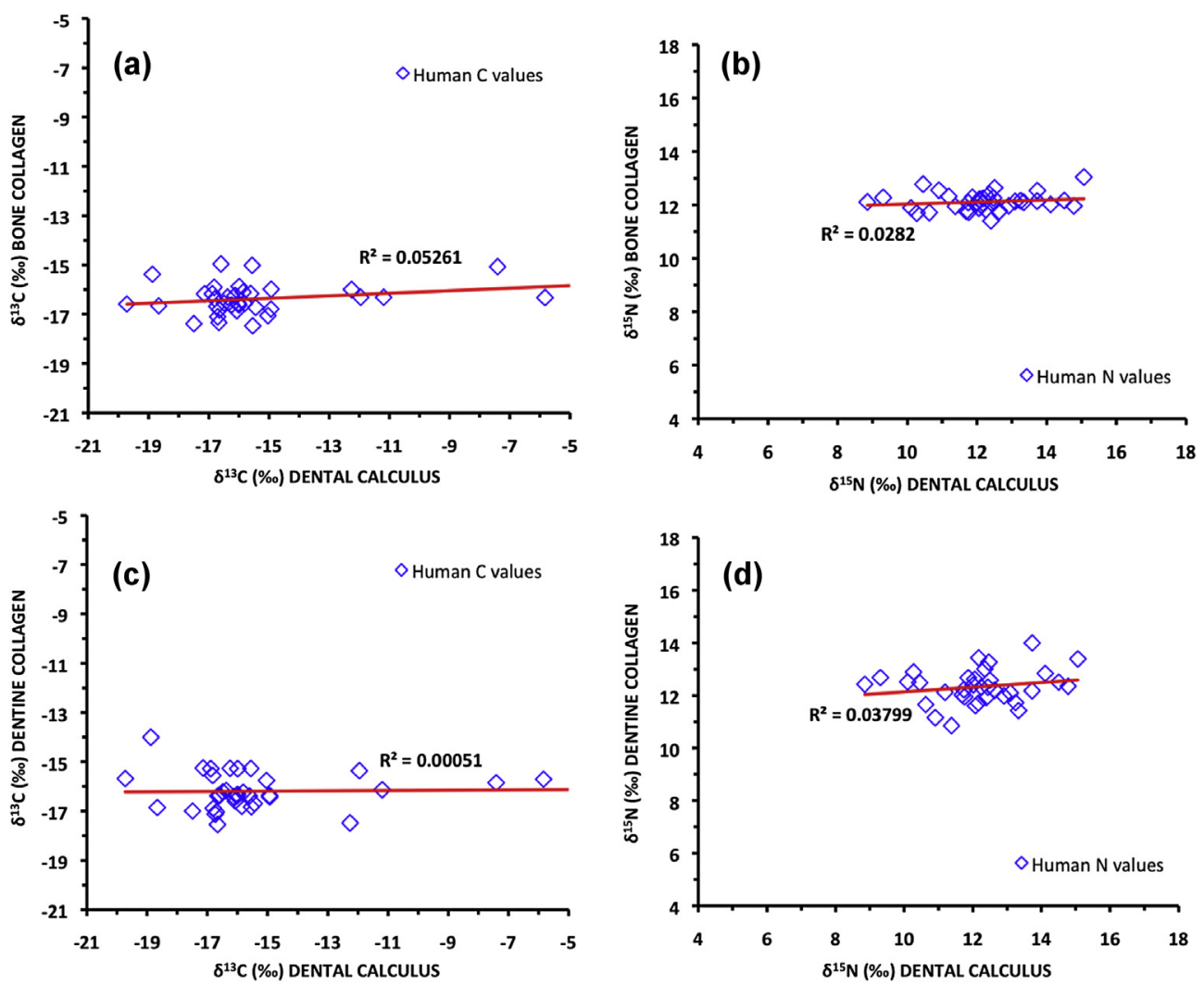

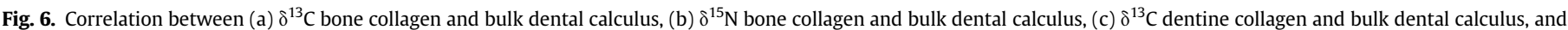

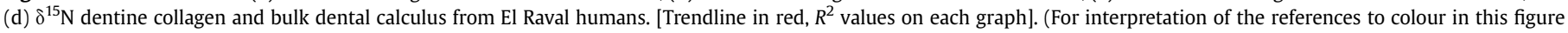
legend, the reader is referred to the web version of this article.).

magnitude. This difference in variance may perhaps be explained by some of the teeth having dentine that formed during periods of breastfeeding, which resulted in elevated nitrogen isotope values compared to typical foods in the diet of these individuals. There is no such ready explanation for the extreme differences in variance between calculus and collagen values, so we must conclude that calculus does not faithfully record the isotopic signal derived from the averaged diets of individuals. Overall, the statistical results show that there is no direct correlation between paired carbon and nitrogen stable isotope ratio values from bulk dental calculus with those from bone or dentine collagen, and thus bulk dental calculus cannot be used directly as a substitute of collagen for past dietary reconstructions.

\section{Discussion}

The observed large differences in the $\delta^{13} \mathrm{C}$ and $\delta^{15} \mathrm{~N}$ values and the associated control parameters $(\% \mathrm{C}, \% \mathrm{~N}, \mathrm{C}: \mathrm{N})$ between calculus and collagen highlights the problem that we do not know what we are really looking at when analysing the carbon and nitrogen isotope values of bulk dental calculus. Calculus likely has a mixed isotopic signature originating from several sources. It can contain a variety of trapped food particles (plants, meat, etc.), bacteria and bacterial proteins, human proteins, and any number of other materials that could become incorporated into the endogenous mineral matrix. The calculus constituents that come directly from the food will not show the same isotopic composition as those constituents that derive from the human or from the oral bacteria. All of these isotope sources are mixed together in unknown proportions, and potentially vary between dental calculus deposits in different locations in the same mouth, and certainly vary among individuals. These uncertainties make it virtually impossible to discern what the carbon and nitrogen isotope values of bulk dental calculus can tell us about diet.

A second important point in the interpretation of the isotopic results of the analysis of calculus is that there is no information on the time scale the dietary reconstruction represents. While bone collagen corresponds to the average protein consumption of the last years of life, and dentine collagen provides information for a specific time span of childhood depending on the tooth type, the

Table 2

Results of F-test of paired variances for $\delta^{13} \mathrm{C}$ and $\delta^{15} \mathrm{~N}$ values between bone collagen and dentine collagen, bone collagen and bulk calculus, dentine collagen and bulk calculus.

\begin{tabular}{|c|c|c|c|}
\hline F-test of paired variances & Bone collagen vs. dentine collagen & Bone collagen vs. bulk calculus & Dentine collagen vs. bulk calculus \\
\hline \multirow[t]{3}{*}{$\delta^{13} \mathrm{C}$} & Bone collagen variance $=0.38$ & Bone collagen variance $=0.38$ & Dentine collagen variance $=0.54$ \\
\hline & Dentine collagen variance $=0.54$ & Bulk calculus variance $=7.75$ & Bulk calculus variance $=7.75$ \\
\hline & $F=0.6906, d f=34, p=0.2854$ & $F=0.0485, d f=34, p=2.312 \mathrm{e}-14$ & $F=0.0702, d f=34, p=6.482 \mathrm{e}-12$ \\
\hline \multirow[t]{3}{*}{$\delta^{15} \mathrm{~N}$} & Bone collagen variance $=0.11$ & Bone collagen variance $=0.11$ & Dentine collagen variance $=0.41$ \\
\hline & Dentine collagen variance $=0.41$ & Bulk calculus variance $=2.05$ & Bulk calculus variance $=2.05$ \\
\hline & $F=0.2577, d f=34, p=0.0001511$ & $F=0.0522, d f=34, p=7.248 \mathrm{e}-14$ & $F=4.9357, d f=34, p=1.05 \mathrm{e}-05$ \\
\hline
\end{tabular}


formation time of dental calculus seems to vary widely even between individuals from the same population. There is no way to estimate what period of an individual's life is captured in the isotopic values from calculus. All of these unknowns, together with the lack of correlation between collagen and bulk calculus carbon and nitrogen isotope values, suggest that bulk dental calculus isotopic analyses cannot substitute for isotope analyses on collagen as a dietary marker when studying individuals. We acknowledge that average bulk calculus values for a population may be similar to those from collagen (at least in our study population from El Raval), but feel strongly that the uncertainties at the individual level are sufficient to suggest that the application of this new approach must be taken with extreme caution. We therefore suggest that bulk calculus be used for stable isotope analysis only when no other skeletal material with well-known biochemistry is available, and only for interpretation of general dietary trends at the population, not individual, level. Much further work on modern and archaeological material is needed to clarify which of the calculus constituents is the main source of the isotope signal, and whether it is possible to isolate parts of the calculus that can provide an accurate dietary signal.

\section{Conclusions}

While the formation and composition of collagen in different body tissues is well known, the formation processes and composition of dental calculus can be highly variable among and within individuals. As we also show in this paper, carbon and nitrogen isotopic analysis on bone and dentine collagen show no correlation with those on bulk dental calculus from same individuals. Thus, isotopic analysis of dental calculus should not be treated in the same manner as that of collagen when doing dietary interpretations.

Further isotopic analysis on the isolated organic and mineral fractions from dental calculus will give a better insight into their role as potential isotopic dietary markers. Until then, we do not recommend carbon and nitrogen isotope analysis on dental calculus as an approach that will yield useable past dietary information. When they are available, it is better to use other skeletal materials (e.g. bone, teeth, hair, nails) with well-known compositions and formation times for isotopic analysis. If only dental calculus is accessible for analysis, we suggest that priority is given to other techniques that provide information on food consumption, such as the study of plant microremains, metagenomics and/or proteomics.

\section{Acknowledgements}

We thank Julio Trelis (Ayuntamiento de Crevillent) for granting the access to the skeletal material, Noelia Rangel at the Universitat de València, Prof. Jean-Jacques Hublin and Sven Steinbrenner at the Department of Human Evolution at the MPI-EVA. We would like to acknowledge the Plant Foods Group for help and support along the way. We also thank the four anonymous reviewers for their helpful comments. ON was funded by a DFG stipend (NE1666/1-1). This research was funded by the Max Planck Society.

\section{Appendix A. Supplementary data}

Supplementary data related to this article can be found at http:// dx.doi.org/10.1016/j.jas.2014.03.026.

\section{References}

Adler, C.J., Dobney, K., Weyrich, L.S., Kaidonis, J., Walker, A.W., Haak, W., Bradshaw, C.J.A., Townsend, J., Sołtysiak, A., Alt, K.W., Parkhill, J., Cooper, A.,
2013. Sequencing ancient calcified dental plaque shows changes in ora microbiota with dietary shifts of the Neolithic and Industrial revolutions. Nat. Genet. 45, 450-455.

Ambrose, S.H., 1993. Isotopic analysis of Paleodiets: methodological and interpretative considerations. In: Stanford, M.K. (Ed.), Investigations of Ancient Human Tissue: Chemical Analyses in Anthropology. Gordon and Breach Science Publishers, Langhorne, pp. 59-130.

Ambrose, S.H., Norr, L., 1993. Experimental evidence for the relationship of the carbon isotope ratios of whole diet and dietary protein to those of bone collagen and carbonate. In: Lambert, J.B., Gruppe, G. (Eds.), Prehistoric Human Bone: Archaeology at the Molecular Level. Springer Verlag, Berlin, pp. $1-37$.

Beaumont, J., Gledhill, A., Lee-Thorp, J., Montgomery, J., 2012. Childhood diet: a closer examination of the evidence from dental tissues using stable isotope analysis of incremental human dentine. Archaeometry 55 (2), 277-295.

Brown, T.A., Nelson, D.E., Vogel, J.S., Southon, J.R., 1988. Improved collagen extraction by modified Longin method. Radiocarbon 30, 171-177.

Chisholm, B.S., Nelson, D.E., Schwarcz, H.P., 1982. Stable carbon isotope ratios as a measure of marine versus terrestrial protein in ancient diets. Science 216, 1131 1132.

De Miguel Ibáñez, P., 2007. Anexo. Necrópolis mudéjar de Crevillent. Estudio osteoarqueológico. Lucentum 26, 221-231.

De Niro, M.J., 1985. Postmortem preservation and alteration of in vivo bone collagen isotope ratios in relation to palaeodietary reconstruction. Nature 317, 806-809.

De Niro, M.J., Epstein, S., 1981. Influence of diet on the distribution of nitrogen isotopes in animals. Geochim. Cosmochim. Acta 49, 97-115.

De Niro, M.J., Epstein, S., 1978. Influence of diet on the distribution of carbon isotopes in animals. Geochim. Cosmochim. Acta 42, 495-506.

Eerkens, J.M., Berget, A.G., Bartelink, E.J., 2011. Estimating weaning and early childhood diet from serail micro-samples of dentin collagen. J. Archaeol. Sci. 38, 3101-3111.

Ghosh, P., Bhattacharya, S.K., Sahni, A., Kar, R.K., Mohabey, D.M., Ambwani, K., 2003. Dinosaur coprolites from the Late Cretaceous (Maastrichtian) Lameta formation of India: isotopic and other markers suggesting a $C_{3}$ plant diet. Cretac. Res. 24, $743-750$.

Guiry, E., Grimes, V., 2013. Domestic dog (Canis familiaris) diets among coastal Late Archaic groups of northeastern North America: a case study for the canine surrogacy approach. J. Anthropol. Archaeol. 32, 732-745.

Hart, J.P., Uruqhart, G.R., Feranec, R.S., Lovis, W.A., 2009. Non-linear relationship between bulk $\delta^{13} \mathrm{C}$ and percent maize in carbonized cooking residues and the potential of false-negatives in detecting maize. J. Archaeol. Sci. 36, 2206-2212.

Hedges, R.E.M., Clement, J.G., Thomas, C.D.L., O'Connell, T.C., 2007. Collagen turnover in the adult femoral mid-shaft: modeled from anthropogenic radiocarbon tracer measurements. Am. J. Phys. Anthropol. 133, 808-816.

Hedges, R.E.M., Reynard, L.M., 2007. Nitrogen isotopes and the trophic level of humans in archaeology. J. Archaeol. Sci. 34, 1240-1251.

Henry, A.G., Ungar, P.S., PAssey, B.H., Sponheimer, M., Rossouw, L., Bamford, M. Sandberg, P., de Ruiter, D.J., Berger, L., 2012. The diet of Australopithecus sediba. Nature. http://dx.doi.org/10.1038/nature11185.

Henry, A.G., Brooks, A.S., Piperno, D.R., 2011. Microfossils in calculus demonstrate consumption of plants and cooked foods in Neanderthal diets (Shanidar III, Iraq; Spy I and II, Belgium). Proc. Natl. Acad. Sci. U. S. A. 108 (2), 486-491.

Jin, Y., Yip, H.K., 2002. Supragingival calculus: formation and control. Crit. Rev. Oral Biol. Med. 13, 426-441.

Katzenberg, M.A., 2000. Stable istope analysis: a tool for studying past diet demography and life history. In: Katzenberg, M.A., Saunders, S.R. (Eds.), Biological Anthropology of the Human Skeleton. Willey-Liss, New York, pp. 305-328.

Lalueza-Fox, C., Juan, J., Albert, R.M., 1996. Phytolith analysis on dental calculus, enamel surface, and burial soil: information about diet and paleoenvironment. Am. J. Phys. Anthropol. 101 (1), 101-113.

Lee-Thorp, J.A., 2008. On isotopes and old bones. Archaeometry 50, 925-950.

Lieverse, A.R., 1999. Diet and the aetiology of dental calculus. Int. J. Osteoarchaeol. 9, 219-232.

Minagawa, M., Wada, E., 1984. Stepwise enrichment of ${ }^{15} \mathrm{~N}$ along food chains: further evidence and the relation between ${ }^{15} \mathrm{~N}$ and animal age. Geochim. Cosmochim. Acta 48, 1135-1140.

Nancollas, G.H., Johnsson, M.A.S., 1994. Calculus formation and inhibition. Adv. Dent. Res. 8, 307-311.

Poulson, S.R., Kuzminsky, S.C., Richard Scott, G., Standen, V.G., Arriaza, B., Muñoz, I., Dorio, L., 2013. Paleodiet in northern Chile through the Holocene: extremely heavy $\delta^{15} \mathrm{~N}$ values in dental calculus suggest a guano-derived signature? J. Archaeol. Sci. 40, 4576-4585.

Power, R.C., Salazar-García, D.C., Wittig, R.G., Henry, A.G., 2014. Assessing use and suitability of scanning electron microscopy in the analysis of microremains in dental calculus. J. Archaeol. Sci. http://dx.doi.org/10.1016/j.jas.2014.04.016.

Richards, M.P., Hedges, R.E.M., 1999. Stable isotope evidence for similarities in the types of marine foods used by Late Mesolithic humans at sites along the Atlantic coast of Europe. J. Archaeol. Sci. 26, 717-722.

Salazar-García, D.C., Aura, E., Olària, C., Talamo, S., Morales, J.V., Richards, M.P., 2014 Isotope evidence for the use of marine resources in the Eastern Iberian Mesolithic. J. Archaeol. Sci. 42, 231-240.

Salazar-García, D.C., Power, R.C., Sanchis-Serra, A., Villaverde, V., Walker, M.J. Henry, A.G., 2013. Neanderthal diets in central and southeastern Mediterranean Iberia. Quat. Int. 318, 3-18. 
Salazar-García, D.C., Coltrain, J.B., Richards, M.P., Henry, A.G., 2012. Stable isotopes from dental calculus. In: 77th Annual Meeting of the Society for American Archaeology, Oral Presentation.

Scheie, A.A., 1994. Mechanisms of dental plaque formation. Adv. Dent. Res. 8, $246-$ 253.

Schoeller, D.A., 1999. Isotope fractionation: why aren't we what we eat? J. Archaeol. Sci. 26, 667-673.

Schoeninger, M.J., De Niro, M., 1984. Nitrogen and carbon isotopic composition of bone collagen from marine and terrestrial animals. Geochim. Cosmochim. Acta 48, 625-639.

Schoeninger, M., De Niro, M., Tauber, H., 1983. Stable nitrogen isotope ratios of bone collagen reflect marine and terrestrial components of prehistoric human diet. Science 220, 1381-1383.

Schwarcz, H.P., Schoeninger, M.J., 1991. Stable isotope analyses in human nutritional ecology. Yearb. Phys. Anthropol. 34, 283-321.

Scott, G.R., Poulson, S.R., 2012. Stable carbon and nitrogen isotopes of human denta calculus: a potentially new non-destructive proxy for paleodietary analysis. J. Archaeol. Sci. 39, 1388-1393.

Scott Cummings, L., Magennis, A., 1997. A phytolith and starch record of food and grit in Mayan human tooth tartar. In: Pinilla, A., Juan-Tresserras, J., Machado, M.J. (Eds.), Estado actual de los estudios de fitolitos en suelos y planta. Monografía 4. Consejo Superior de Investigaciones Científicas, Madrid, pp. 211-218.

Sealy, J. 2001. Body tissue chemistry and paleodiet. In: Brothwell, D.R., Pollard, A.M. (Eds.), Handbook of Archaeological Sciences. Wiley, Chichester, pp. 269-279.
Trelis Martí, J., Ortega Pérez, J.R., Reina Gómez, I., Esquembre Bebia, M.A., 2010. El Cementeri Mudèjar del Raval (Crevillent-Alacant). La Rella 23, 213-252.

Trelis Martí, J., Ortega Pérez, J.R., Reina Gómez, I., Esquembre Bebia, M.A., 2009. El cementerio mudéjar del Raval (Crevillent-Alicante). Arqueol. Territ. Mediev. 16, 179-216.

Trelis Marti, J., Ortega Pérez, J.R., Tejerina Antón, D., Esquembre Bebia, M.A., 2007. Recientes aportaciones al urbanismo bajomedieval de Crevillent (Alicante): El cementerio mudéjar del Raval. Lucentum 26, 207-220.

Van der Merwe, N.J., Vogel, J.C., $1978 .{ }^{13} \mathrm{C}$ content of human collagen as a measure of prehistoric diet in Woodland North America. Nature 276, 815-816.

Van Klinken, G.J., 1999. Bone collagen quality indicators for palaeodietary and radiocarbon measurements. J. Archaeol. Sci. 26, 687-695.

Warinner, C., Matias Rodrigues, J.F., Vyas, R., Trachsel, C., Shved, N., Grossman, J., Radini, A., Hancock, Y., Tito, R.Y., Fiddyment, S., Speller, C., Hendy, J., Charlton, S., Luder, H.U., Salazar-García, D.C., Eppler, E., Seiler, R., Hansen, L., Samaniego Castruita, J.A., Barkow-Oesterreicher, S., Teoh, K.Y., Kelstruo, C., Olsen, J.V., Nanni, P., Kawai, T., Willerslev, E., Von Mering, C., Lewis, C.M., Collins, M.J., Gilbert, M.T.P., Rühli, F., Cappellini, E., 2014. Pathogens and host immunity in the ancient human oral cavity. Nat. Genet.. http://dx.doi.org/10.1038/ng.2906.

White, D.J., 1997. Dental calculus: recent insights into occurrence, formation, prevention, removal and oral health effects of supragingival and subgingival deposits. Eur. J. Oral Sci. 105, 508-522. 